McKinnon, L., L. Schmaltz, Y. Aubry, Y. Rochepault, C. Buidin, and C. Juillet. 2022. Female migration phenology and climate conditions explain juvenile Red Knot (Calidris canutus rufa) counts during fall migration. Avian Conservation and Ecology 17(1):9. https://doi.org/10.5751/ ACE-02021-170109

Copyright (C) 2022 by the author(s). Published here under license by the Resilience Alliance.

Research Paper

\title{
Female migration phenology and climate conditions explain juvenile Red Knot (Calidris canutus rufa) counts during fall migration
}

\author{
Laura McKinnon $^{1}$, Lucie Schmaltz ${ }^{2}$, Yves Aubry ${ }^{3}$, Yann Rochepault ${ }^{4}$, Christophe Buidin ${ }^{4}$ and Cedric Juillet $^{5}$ \\ ${ }^{1}$ York University Glendon Campus, Department of Multidiscipinary Studies and Graduate Program in Biology, Toronto, Ontario, \\ Canada, ${ }^{2}$ Mavromatika (mavromatica.com), Riom, France, ${ }^{3}$ Canadian Wildlife Service, Environment and Climate Change Canada, \\ Quebec, Canada, ${ }^{4}$ Association le Balbuzard, Rivière-Saint-Jean, Québec, Canada, ${ }^{5}$ Royal Ontario Museum, Toronto, Ontario, \\ Canada
}

\begin{abstract}
The management of avian populations at risk requires accurate estimates of vital rates across age and sex classes to effectively identify the most vulnerable demographic and support conservation actions. In the endangered Red Knot (Calidris canutus rufa), there are relatively few reliable estimates of reproductive success because they breed in such low densities across such a large and relatively inaccessible area in Arctic Canada. The purpose of this study is to test whether a migratory time lag between adult male and female knots during post-breeding southbound migration could be a reliable index of reproductive success for this species. If so, we expected to find a positive relationship between a time lag in male migration and the number or proportion of juveniles present at the same fall migration site. To test this hypothesis, we analyzed 13 years of capture-mark-recapture and census data from an important staging area during southbound migration. We found a strong and consistent age and sex-specific chronology; median passage dates for females were approximately 2 weeks earlier than males, with juveniles following 1 month later than adults of both sexes. For most years, there was a significant time lag of up to 27 days between females and males. However, we found no evidence to support that this time lag explained variation in the number of juveniles at the stopover site each year. Instead, we found that the timing of female migration along with an index of environmental conditions on the breeding grounds and during migration best described the proportion of juveniles present during migration. Overall, our results cast doubt on the reliability of the male migratory time lag as an indicator of breeding success.
\end{abstract}

\section{La phénologie de migration des femelles et les conditions climatiques expliquent le nombre de bécasseaux maubèche (Calidris canutus rufa) pendant la migration d'automne}

RÉSUMÉ. La gestion des populations aviaires menacées requiert des estimations précises des indices vitaux en fonction des catégories d'âge et de sexe afin d'identifier efficacement les populations démographiques vulnérables et de soutenir des mesures de conservation. Chez les bécasseaux maubèches menacés (Calidris canutus rufa), il existe relativement peu d'estimations fiables du succès de la reproduction, car ils se reproduisent en densités très faibles sur des territoires extrêmement vastes et relativement inaccessibles dans les régions arctiques du Canada. Cette étude a pour objet de découvrir si un délai migratoire entre les groupes de mâles et de femelles adultes pendant la migration vers le sud post-reproduction pourrait être un indice fiable du succès reproductif de cette espèce. Si tel est le cas, nous nous attentions à trouver une relation positive entre le délai entre la migration des mâles et le nombre ou la proportion des jeunes présents sur le même site de migration d'automne. Pour tester cette hypothèse, nous avons analysé 13 années de données de capture-marquage-recapture et de recensement sur une vaste zone de rassemblement pendant la migration vers le sud. Nous avons constaté une chronologie forte et cohérente spécifique à l'âge et au sexe ; les dates de passage médianes des femelles intervenaient environ 2 semaines avant celles des mâles, les jeunes des deux sexes suivant 1 mois après les adultes. Le plus souvent, il existait un délai significatif pouvant atteindre 27 jours entre le passage des femelles et celui des mâles. Nous n'avons cependant trouvé aucune preuve indiquant que ce délai expliquait les variations du nombre de jeunes présents sur le site de passage chaque année. En fait, nous avons constaté que la date de la migration des femelles, accompagné d'un indice concernant les conditions environnementales sur les territoires de reproduction et pendant la migration permettait de décrire au mieux à la proportion de jeunes présents au cours de la migration. Globalement, nos résultats jetaient des doutes sur la fiabilité du délai migratoire des mâles en tant qu'indicateur du succès de la reproduction.

Key Words: Calidris; migration phenology; shorebirds; stopover ecology

\section{INTRODUCTION}

In birds, successful recruitment of juveniles into the breeding segment of a population requires that adults experience environmental conditions conducive to breeding attempts (high breeding propensity), that breeding attempts are successful (high nest success), and that hatchlings survive to a reproductive age (high juvenile survival). Although adult survival is known, both theoretically and empirically, to be the most important factor 
contributing to population growth rates in birds (Lampila et al. 2006) and across taxa in general (Pfister 1998, Gaillard and Yoccoz 2003), the importance of recruitment, especially in declining populations, should not be underestimated (Westemeier et al. 1998). Other than immigration, recruitment is the only way to increase the number of breeding adults in a population. Arcticnesting shorebird populations across North America have experienced drastic declines in population size in recent decades (Andres et al. 2012); therefore, there is urgency to better understand factors affecting adult survival, reproductive success, and recruitment. Consequently, there has been an influx of studies on adult survival and reproductive success (Weiser et al. 2018a, Weiser et al. 2018b), but few studies have been able to track juveniles after they leave the natal grounds to provide an indication of juvenile survival, movement, and recruitment potential (but see Anderson et al. 2019).

The Red Knot (Calidris canutus rufa) is an arctic-nesting shorebird that breeds in low densities across the south and central eastern Canadian Arctic (Lathrop et al. 2018). During fall migration, C. c. rufa flies along the Central America and/or the Western Atlantic flyways to reach three main non-breeding sites on the shores of the southeastern USA and the Caribbean Islands, northeastern Brazil, and southern Argentina (Baker et al. 2013, Lyons et al. 2017). The C. c. rufa population has experienced a dramatic $70 \%$ decline in population size over the past 15 years (Environment and Climate Change Canada (ECCC) 2016) with latest estimated population size at approximately 42,000 (Andres et al. 2012). They are currently listed as endangered in Canada (Committee on the Status of Endangered Wildlife in Canada (COSEWIC) 2007) and threatened in the USA (U.S. Fish and Wildlife Service (USFWS) 2014). The decline has been relatively well documented, and although factors are multiple, the decline has been attributed primarily to the over-harvesting of horseshoe crabs at one critical spring staging site of the Red Knots in Delaware Bay, USA (Niles et al. 2009, McGowan et al. 2011). As horseshoe crab eggs form an important component of the diet of staging knots, a decline in this seasonal food peak has led to reduced fitness of adult $C$. c. rufa using Delaware Bay (Baker et al. 2004). Other factors that may affect the survival of both adults and juveniles and limit recruitment include toxic red tide events (Baker et al. 1998, van Deventer et al. 2012), raptor population recovery (Lank et al. 2003, Ydenberg et al. 2004), and shifts in cyclone intensity and habitat deterioration (Convertino et al. 2011).

Over the past two decades there has been a concerted international effort to monitor population vital rates to elucidate the underlying mechanisms driving the decline. The population has been well monitored at some staging areas along the western Atlantic flyway and on the non-breeding grounds, and several studies have indicated relatively high adult survival rates with low annual variability (McGowan et al. 2011, Schwarzer et al. 2012). Despite successful monitoring efforts along the flyway, efforts to monitor reproduction on the breeding grounds have been less successful. Calidris c. rufa breeds in such low densities across such a large area that estimates of breeding productivity have been constrained to a few sporadic estimates of nest success based on a limited number of nests (Baker et al. 2013). In response to this lack of data, an index of breeding productivity has been proposed based on differences in the migration phenology at migratory stopovers. In many shorebird species, there is a well documented migratory time lag between adult and juvenile migration phenology; juveniles migrate later than adults (Helseth et al. 2005). For Red Knots, the migratory time lag index is based upon the assumption that the differential timing of migration between sexes stems from differential duration of parental care for female and male Red Knots (Lyons et al. 2017). Red Knots exhibit biparental incubation. However post-hatch parental care is provided primarily by males (Baker et al. 2013), permitting females to leave the breeding grounds earlier and arrive at postbreeding migration stopover sites first, followed by males and juveniles. Based on the index, a year of successful breeding would be characterized by an increased lag between female and male migration phenology. Although intuitive, and with long-held theoretical foundations (Myers 1981), the index is lacking substantial empirical evidence.

The purpose of this study is to investigate the hypothesis that a migratory time lag between adult male and female knots is a reliable index of reproductive success. If the index is reliable, we expect to find a positive relationship between a time lag in male migration and the number or proportion of juveniles present at the same post-breeding migration site. To test this hypothesis, we take advantage of 13 years of data from a long-term capturemark-recapture and census program established at one of the most important known staging areas for C. c. rufa juveniles during southbound post-breeding migration, the Mingan Archipelago National Park Reserve in Quebec, Canada. Given that there are important extrinsic factors such as climatic conditions that may influence both reproductive success and timing of migration in both males and females, we adopted a multiple inference approach that involved the comparison of several competing hypotheses in order to explain variation in the proportion of juveniles present during migration.

\section{METHODS}

\section{Study Area}

This study was conducted during the summers of 2006-2018 on five islands located within the Mingan Archipelago National Park Reserve $\left(50.12^{\circ} \mathrm{N}, 63.55^{\circ} \mathrm{W}\right)$ situated along the north shore of the Gulf of St. Lawrence River, Quebec, Canada. (Fig. 1). These limestone islands are characterized by extensive mudflats on their south side. At low tides, the large extent of exposed pools and vegetation offers a diversity of marine invertebrates for shorebirds to feed on (Buidin et al. 2010).

\section{Migration Monitoring}

Surveys were conducted from July to early November each year on the three main islands, Niapiskau, Quarry, and Grand-Ile, by one to four individuals almost daily. Another two islands, Île Nue and Île aux Perroquets, were also visited sporadically, especially when juveniles were present. All observers had a minimum of 3 years of experience with shorebird census and resighting of banded individuals. In addition, three of the most experienced observers (YA, YR, CB) were present for all 13 years of the study, providing a very high level of experience and consistency between years. All efforts were made to count adults and juveniles separately during the censuses; however, in large flocks, the 
Fig. 1. Map of study sites.

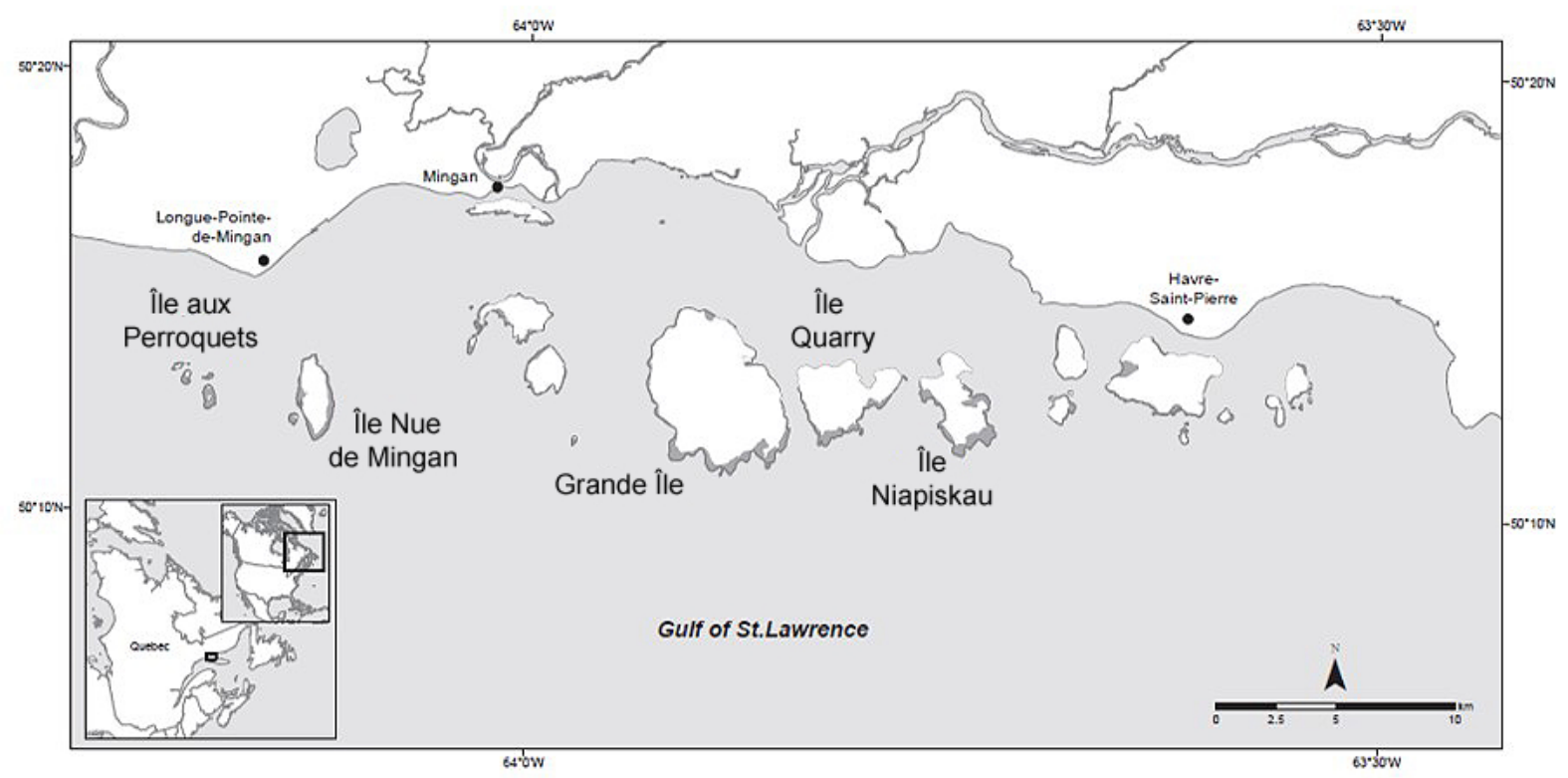

number of juveniles may have been underestimated, and therefore, reported counts of juveniles should be considered a minimum.

Red Knots were captured using cannon nets or net-guns during the highest diurnal high tides $(>1.40 \mathrm{~m})$ when birds were forced to roost on the island's shoreline or rocky outcrops (Buidin et al. 2015). In early July, diurnal high tides are rare, therefore, there were very few captures early in the season. Most of the capture events occurred from late July onward when diurnal high tides were more frequent. Once captured, each individual was banded with a U.S. Fish and Wildlife Service metal band, and a uniquely inscribed white plastic flag on the left tarsus. Birds were aged as hatch year (HY, juveniles) or after hatch year (AHY, adults) based on plumage. Measurements of body mass, culmen, and flattened wing length were recorded, and a blood sample was collected to permit subsequent molecular sexing of individuals. Between 2007 and 2018, a total of 1183 new individuals were captured and sexed: 190 (16\%) AHY females, 395 (33\%) AHY males, 28 (24\%) HY females, and $317(27 \%)$ HY males. We also recaptured a total of 47 previously banded individuals: $12(25 \%)$ AHY females, 28 (60\%) AHY males, 2 (4\%) HY females and 5 (11\%) HY males.

Previously captured individuals were resighted across the five islands each visited multiple times per week. Observations occurred 6 days per week on average, from 0900 to 1500 . Observers moved throughout the study area according to the tidal cycles to find favorable positions for band reading. Observations were made using a spotting scope with a $15-60 \times$ zoom.

\section{Migration Phenology}

Sex differences in migration phenology of adult C. c. rufa were assessed using resighting data as they were best distributed over time compared with capture events, which were less frequent and more sporadic. To describe migration phenology, we used the median migration date, defined as the date upon which $50 \%$ of the banded/marked population has passed through the site. Differences in the median migration date between the sexes each year were tested via a permutation test using the percentile Test function in package "rcompanion" in Program R v.3.5.1 (R Core Team 2019, Mangiafico 2020). We also calculated the time lag between the migratory date of adult males and females defined as the difference between the median resighting dates of females and males; positive values indicate that males migrate later than females.

Across all years, there were not enough capture events of juvenile C. c. rufa to provide a thorough description of juvenile phenology. Therefore, we used the census data where the presence of juveniles was specified during daily counts. We considered the median migration date from daily counts where juveniles were present as an indication of juvenile migration timing. In 2015 and 2016, juvenile captures were more numerous $(n=82$ and 189, respectively) and relatively spread over time (from 15 August to 17 October and 21 August to 29 October, respectively). For these 2 years, we calculated the median migration date of juvenile males and females and investigated whether timing of capture differed between sexes using permutation tests as we did for adults above.

\section{Sex Ratio}

We describe the variation of sex ratio (i.e., the proportion of males) among adult birds using both resighting and capture events. Estimating sex ratios from resighting data has the advantage of a larger sample size in both space and time; however, estimating sex ratios from captures provides a more accurate snapshot of sex ratios within distinct foraging groups. Differences in sex ratios between juveniles were examined using capture events only. Because of sparse capture events, we chose to pool all years together (2007-2017) and examined the variation in sex ratio within twelve 10-day periods for juveniles and adults. In each age 
Table 1. Differences in median migration date between resightings of AHY females (F) and males (M) based on permutation tests. Time Lag is defined as the female median-male median resighting date. Median migration dates for HY are provided for 2 years when captures had sufficient temporal spread. Day of year $200=19$ July.

\begin{tabular}{|c|c|c|c|c|c|c|}
\hline Year & F-AHY (n) & M-AHY (n) & $\mathrm{p}$ & Time lag (days) & F-HY (n) & M-HY (n) \\
\hline 2006 & $201(80)$ & $207(2)$ & & -6 & & \\
\hline 2007 & $213(67)$ & $225(20)$ & 0.0172 & 12 & & \\
\hline 2008 & $209(89)$ & $225(143)$ & $<0.0001$ & 16 & & \\
\hline 2009 & $214(83)$ & $220(98)$ & 0.0496 & 6 & & \\
\hline 2010 & $204(60)$ & $231(138)$ & $<0.0001$ & 27 & & \\
\hline 2011 & $205(30)$ & $225(99)$ & 0.001 & 20 & & \\
\hline 2012 & $210.5(28)$ & $220(118)$ & 0.0072 & 10 & & \\
\hline 2013 & $198(58)$ & $225(91)$ & $<0.0001$ & 27 & & \\
\hline 2014 & $205(37)$ & $216.5(52)$ & 0.002 & 11 & & \\
\hline 2015 & $209(55)$ & $208(94)$ & 0.348 & -1 & $285(35)$ & $285(47)$ \\
\hline 2016 & $203(61)$ & $222(67)$ & $<0.0001$ & 19 & 273(139) & $273(150)$ \\
\hline 2017 & $212(7)$ & $230(89)$ & $<0.0001$ & 18 & & \\
\hline 2018 & $213(32)$ & $229(83)$ & 0.0048 & 16 & & \\
\hline ALL & $210(687)$ & 225 (1094) & $<0.0001$ & 15 & $271(281)$ & $271(317)$ \\
\hline
\end{tabular}

Abbreviations:, AHY - after hatch year; adult, F-AHY - Female adult, F-HY - Female juvenile, M-AHY - Male adult, M-HY - Male juvenile

class, we examine whether the sex ratio differs from an even sex ratio using a binomial test (binom.test function in Program $\mathrm{R} ; \mathrm{R}$ Core Team 2019).

\section{Explaining Variation in Population Size of Juveniles during Census}

We explored whether interannual variation in the number of juveniles observed during counts could be explained by (1) phenology of male and female migration, (2) the observed time lag between male and female migration, (3) indices of environmental conditions experienced on the breeding grounds, and (4) an index of environmental conditions experienced during the southbound migration. We assessed the population size of juveniles during counts using two measures: (1) maximum annual count during census and (2) the proportion of juveniles based on maximum annual counts for both adults and juveniles. For covariates, we used the median migration date for males and females as well as the time lag (male median-female median) as defined above. Our first index of environmental conditions on the breeding ground was the means of the monthly North Atlantic Oscillation (NAO) values for May, June, and July obtained from the National Oceanic and Atmospheric Administration website (https://www.cpc.ncep.noaa.gov/products/precip/CWlink/pna/nao. shtml). Our second index of environmental conditions on the breeding ground was the average weekly snow cover extent across Northern America (no Greenland) for May, June, and July (https://climate.rutgers.edu/snowcover/table_area.php?ui_set=2). As an index of environmental conditions during southbound post-breeding migration, we used the means of the monthly NAO values for August, September, and October obtained from the National Oceanic and Atmospheric Administration website noted above. High NAO values are indicators of colder harsher weather.

Due to the presence of high multicollinearity in our data set (several high pairwise correlations of $r>7.0$ ), we ran a principal components analysis on the six explanatory variables to generate a set of synthetic orthogonal variables (Joliffe 2002, Juillet et al. 2012, Dormann et al. 2013) using the package "psych" in R. v.
2.14.1. (R Core Team 2019) . A varimax rotation was applied to the retained axes to improve biological interpretation. We then generated a set of seven a priori defined models based on a combination of additive effects of our new synthetic factors to explain variation in (a) maximum juvenile counts and (b) proportion of juveniles observed during the census. We used generalized linear models to explain variation in maximum juvenile counts (negative binomial distribution) and the proportion of juveniles (binomial distribution). We selected the most informative model using Akaike's Information Criterion (AIC) corrected for small sample sizes (AICc; Burnham and Anderson 2002). The model with the lowest AIC indicated the most informative model.

\section{RESULTS}

\section{Migration Phenology}

Adults were counted during census from 9 July to 27 October across years. Median passage date of adults based on census was 9 August. The first juveniles arrived 7 August and were counted during census until 12 November, with a median passage date of 4 September.

Based on observations of banded individuals of known sex, the median migration date of female AHY was 29 July (range 17 July2 August), whereas males were consistently later at 13 August (range 26 July-18 August; Fig. 2; Table 1). Median migration dates varied by year for both sexes; however, males exhibited a significant time lag in 11 of 13 years (Table 1). For the 2 years where we had sufficient data for juveniles of known sex, no time lags were detected for that age class (Table 1).

\section{Sex Ratio}

After 8 August, adult sex ratios were significantly male biased for both captures and observations of individuals until the end of the monitoring period (Table 2). There was no detectable sex ratio bias in juveniles, with the exception of one period (7-17 October), which was significantly male biased (Table 2); however, most of the juvenile sex ratios were calculated based on low sample sizes. 
Table 2. Sex ratio by 10-day period for AHY resightings and captures, and HY captures, all years combined

\begin{tabular}{|c|c|c|c|c|c|c|c|c|c|}
\hline \multirow[t]{2}{*}{ Period } & \multicolumn{3}{|c|}{ AHYOBS } & \multicolumn{3}{|c|}{ AHYCAP } & \multicolumn{3}{|c|}{ HY } \\
\hline & $\mathrm{M}$ & $\mathrm{F}$ & Ratio & $\mathrm{M}$ & $\mathrm{F}$ & Ratio & $\mathrm{M}$ & $\mathrm{F}$ & Ratio \\
\hline 1 & 77 & 98 & $0.44 * * *$ & 1 & 3 & 0.25 & & & \\
\hline 2 & 155 & 225 & $0.41 * * *$ & 19 & 28 & 0.40 & & & \\
\hline 3 & 131 & 165 & 0.44 & 77 & 111 & $0.41^{*}$ & & & \\
\hline 4 & 402 & 150 & $0.73^{* * *}$ & 141 & 34 & $0.81 * * *$ & 1 & 1 & 0.50 \\
\hline 5 & 301 & 46 & $0.87^{* * *}$ & 144 & 13 & $0.92 * * *$ & 9 & 9 & 0.50 \\
\hline 6 & 28 & 3 & $0.90 * * *$ & 11 & 0 & & 109 & 94 & 0.54 \\
\hline 7 & & & & & & & 27 & 24 & 0.53 \\
\hline 8 & & & & & & & 5 & 5 & 0.50 \\
\hline 9 & & & & 2 & 0 & & 93 & 92 & 0.50 \\
\hline 10 & & & & 0 & 1 & & 52 & 28 & $0.65^{* *}$ \\
\hline 11 & & & & & & & 12 & 12 & 0.50 \\
\hline 12 & & & & & & & 9 & 16 & 0.36 \\
\hline
\end{tabular}

* $(\mathrm{p}<0.05),{ }^{* *}(\mathrm{p}<0.01), * * *(\mathrm{p}<0.0001), \quad$ Abbreviations: AHY - after hatch year, AHYCAP - after hatch year captured, AHYOBS - after hatch year observed, F - Female, HY - hatch year, M - Male

Fig. 2. Phenology of female $(n=687)$ and male $(n=1094)$ adults based on observations of individuals in the field between 2006 and 2018.
Female AHY

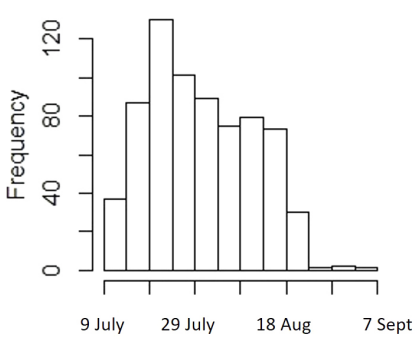

Date
Male AHY

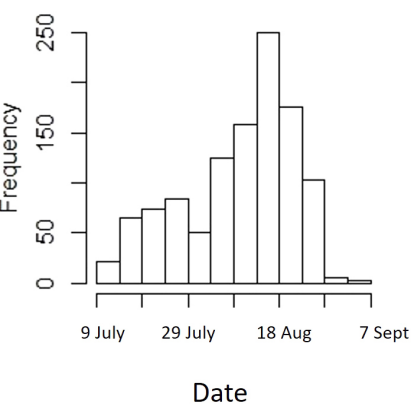

\section{Explaining Variation in Population Size of Juveniles during Census}

\section{Principal components analysis}

We retained the first three components of the principal components analysis (PCA) as together they explained $92 \%$ of variation in the data set (Joliffe 2002) and exhibited high loadings of each variable of interest ( $>0.60$; Table 3$)$. Snow cover during the breeding season, median male migration dates, and the male migratory time lag contributed the most to the first rotated component ( $\mathrm{RC} 1$ ) and were positively correlated with it (Table 3 ). The NAO during the migration and median female migration dates loaded the most and was positively correlated with the second rotated component (RC2; Table 3). Finally, on the third rotated component (RC3), NAO during the breeding season contributed the most and was positively correlated. We interpreted $\mathrm{RC} 1$ as a combined index of snow cover during the breeding season and male migration phenology (including the lag). The RC2 was interpreted as a combined index of weather conditions during migration (high values indicative of cold temperatures) and female migration phenology. Finally, RC3 was interpreted as our index of weather conditions during the breeding season (high values indicative of cold temperatures).

Table 3. Loadings of each covariate on the three rotated principal components (Varimax method). Interpretation of axes was based on the three highest loadings, which are indicated in bold.

\begin{tabular}{llll}
\hline \hline Variable & $\mathrm{RC} 1$ & $\mathrm{RC} 2$ & $\mathrm{RC} 3$ \\
\hline Snow Cover Breeding Season & $\mathbf{0 . 7 7}$ & 0.51 & 0.19 \\
NAO Breeding Season & 0.03 & -0.04 & $\mathbf{0 . 9 7}$ \\
NAO Migration & 0.45 & $\mathbf{0 . 6 1}$ & 0.56 \\
Median Migr. Female & -0.03 & $\mathbf{0 . 9 6}$ & -0.07 \\
Median Migr. Male & $\mathbf{0 . 9 2}$ & 0.16 & 0.07 \\
Time Lag Male-Female & $\mathbf{0 . 9 8}$ & -0.20 & 0.02 \\
Cumulative Variance explained & 0.43 & 0.70 & 0.92 \\
\hline Abbreviations: Migr. - migration, & NAO - North Atlantic Oscillation
\end{tabular}

\section{Maximum juvenile counts}

Variation in juvenile maximum counts during census was best described by our intercept-only model (Table 4). However, two models fell within 2 AICc of this top model. The first competitive model $(\triangle \mathrm{AICc}=1.17$; Table 4$)$ included a negative effect of $\mathrm{RC} 2$ : as environmental conditions during southbound migration improved (lower NAO values) and females migrated through Mingan earlier, the maximum juvenile counts increased. The second competitive model $(\triangle \mathrm{AICc}=1.49$; Table 4$)$ included a negative effect of $\mathrm{RC} 3$ : as conditions on the breeding grounds improved (lower NAO values), maximum juvenile counts increased. However, given that these models were competitive with the intercept-only model (indicating no effects of any variables), there was little to no support for these models.

\section{Proportion of juveniles}

Variation in the proportion of juveniles counted during census was best described by a model including a negative effect of RC2 and RC3 (Table 5). As environmental conditions on the breeding grounds and during southbound migration improved (lower NAO values) and the median female migration date was earlier, the proportion of juveniles increased (Table 6). 
Table 4. Model selection results for the generalized linear models (family $=$ negative binomial) explaining variation in the maximum number of juveniles observed during census

\begin{tabular}{lcc}
\hline \hline Models & $\mathrm{K}$ & $\Delta \mathrm{AIC}$ \\
\hline Intercept & 2 & 0 \\
$\mathrm{RC} 3$ & 3 & 1.17 \\
$\mathrm{RC} 2$ & 3 & 1.49 \\
$\mathrm{RC} 1$ & 3 & 3.11 \\
$\mathrm{RC} 2+\mathrm{RC} 3$ & 4 & 3.60 \\
$\mathrm{RC} 1+\mathrm{RC} 2$ & 4 & 5.29 \\
$\mathrm{RC} 1+\mathrm{RC} 3$ & 4 & 5.35 \\
\hline
\end{tabular}

Table 5. Model selection results for the generalized linear models (family = binomial) explaining variation in the proportion of juveniles observed during census

\begin{tabular}{lcc}
\hline \hline Models & $\mathrm{K}$ & $\Delta \mathrm{AIC}$ \\
\hline $\mathrm{RC} 2+\mathrm{RC} 3$ & 4 & 0 \\
$\mathrm{RC} 1+\mathrm{RC} 2$ & 4 & 26.22 \\
$\mathrm{RC} 2$ & 3 & 43.68 \\
$\mathrm{RC} 1+\mathrm{RC} 3$ & 4 & 151.83 \\
$\mathrm{RC} 1$ & 3 & 162.18 \\
$\mathrm{RC} 3$ & 3 & 187.32 \\
Intercept & 2 & 206.10 \\
\hline
\end{tabular}

Table 6. Parameter estimates for the top model explaining variation in the proportion of juvenile counts

\begin{tabular}{lcccc}
\hline \hline Parameter & Estimate & $\mathrm{SE}$ & $\mathrm{z}$ & $\mathrm{p}$ \\
\hline Intercept & -1.98 & 0.02 & -107.17 & $<0.0001$ \\
RC2 & -0.26 & 0.02 & -13.65 & $<0.0001$ \\
RC3 & -0.17 & 0.03 & -6.76 & $<0.0001$ \\
\hline
\end{tabular}

\section{DISCUSSION}

Our results confirm a strong and consistent age and sex-specific chronology of C. c. rufa during the first stage of their southbound migration as they stop over in the Mingan Archipelago. The median passage date of 29 July for adult females was approximately 2 weeks earlier than that of males (13 August). Both captures and observations of banded individuals indicate that sex ratios were significantly male biased during the second half of adult passage. Based on census data, median passage dates of juveniles were almost 1 month later than adults of both sexes. For most years, there was a significant male time lag of up to 27 days; however, we found no evidence to support that this time lag explained variation in the number of juveniles at the stopover site each year. Instead, we found that the timing of female migration, along with our index of environmental conditions on the breeding grounds and during migration, best described the proportion of juveniles present during migration. Overall, our results cast doubt on the reliability of the male migratory time lag as an indicator of breeding success, as this variable did not show up in any of our top models explaining maximum counts or proportions of juveniles during southbound post-breeding migration.

\section{Migration Phenology}

Age-specific chronology of a similar magnitude has been documented in other Red Knot populations during fall migration. On the southern Baltic Coast, Red Knot adults arrive from their breeding grounds in the Siberian Arctic approximately 20-30 days before juveniles (see references in Meissner 2005). A similar pattern has been found in other arctic-nesting shorebirds such as the Western Sandpiper (Calidris mauri) and Dunlin (C. alpina), where adults also migrate south approximately 1 month earlier than juveniles (Ydenberg et al. 2005). In shorebirds, the earlier migration of adults in general is likely driven by a combination of failed breeders and the sex that leaves post-hatch parental care to their mates (Meltofte et al. 2007). This is consistent with our results of female bias in early migrants, as successful females would leave parental care to the males, and failed pairs could account for any early migrating males (Baker et al. 2013).

Sex-specific chronology of migration is not uncommon in shorebirds during spring pre-breeding migration when males are often migrating through stopover sites before females to arrive first on the breeding grounds (Bishop et al. 2004, Muraoka et al. 2009). During fall post-breeding migration, Western Sandpiper males migrated up to 8 days later than females (Ydenberg et al. 2005), whereas at Mingan, the male time lag was up to three times longer (27 days). Myers (1981), suggested that these sex-specific patterns of migration should be expected among Calidrine sandpipers and that they likely indicate a strategy for the females to decrease the risks of long-distance migration by departing the breeding grounds earlier. By leaving very early, females may (1) fly ahead of predators, avoiding the flux of arctic falcons (Lank et al. 2003); (2) fuel up over a longer period and have access to better fuel resources at northern stopover sites before facing their first long overseas flight toward austral non-breeding staging sites (Anderson et al. 2019); and (3) avoid the increasing number of western Atlantic tropical cyclones (Webster et al. 2005) on southbound migration. In Western Sandpipers, female juveniles also migrated earlier than male juveniles. We did not detect any sex-specific chronology within juveniles; however, our data were limited to detect this.

\section{Explaining Variation in Population Size of Juveniles during Census}

With regard to the relationship between the timing of female migration and juvenile counts, our results contrast with those of Meissner (2005). He found that in years with a large number of juvenile counts at their stopover site, both male and female median migration dates were later. In our study, the relationship was only found for female migration phenology, not males. With regard to evidence for the male migratory time lag as an index of productivity, our results align with those of Meissner (2005) as he found almost no evidence for a difference in time lag between years of high ( 7 days male time lag) vs. low juvenile counts ( 8 days male time lag). It is important to note, however, that due to the low refuelling rates for C.c. canutus at the Puck Bay site, Meissner (2005) suggested that the site may be an emergency stopover site for birds and not a main stopover site; therefore, they may not be representative of the entire population. Mingan does not appear 
to be an emergency site given that approximately 9450 birds use the site annually (Lyons et al. 2018), which is $23 \%$ of the total estimated C. c. rufa population (42,000; ECCC 2016). Despite the high proportion of the population using the site, there is still uncertainty as to the extent of the breeding ground origins or if the juveniles and adults are arriving from the same breeding subpopulations. Given that Mingan is one of the few known juvenile migration sites in Canada (closest to the breeding grounds), there is the possibility that, for juveniles at least, we could be sampling a high proportion of the breeding range. If adults are being drained from specific sub-populations, and juveniles from a much wider geographic area, then the proportion of juveniles may not adequately represent reproductive success. However, if juveniles are sampling the entire breeding range, the maximum juvenile counts alone may be a reliable indicator of overall reproductive success regardless of any relation to adult migrations.

\section{CONCLUSIONS}

By documenting the sex and age-specific chronology of C. c. rufa at one of their first post-breeding stopover sites, we are able to test, for the first time, the long-held assumption that a migratory time lag between adult male and female knots can be used an index of reproductive success. Although we did find a significant male time lag most years, we found no evidence to support that this time lag explained variation in the number of juveniles at the stopover site each year. Instead, we found that the timing of female migration along with an index of environmental conditions on the breeding grounds and during migration best described the proportion of juveniles present during migration. It is important to note, however, that our study is not free from biases, as it is not known whether our stopover site represents a mixture of populations for adults, juveniles, or both. Ongoing migration tracking studies (geolocators, satellites) of birds using Mingan will soon resolve this issue. Despite this potential bias, our results still indicate that conservation initiatives should be paying more attention to the females and juveniles themselves, as opposed to males. In this regard, we highlight the importance of the Mingan site for the conservation of C. c. rufa as it is one of the few known stopover sites to provide post-breeding juvenile counts, which likely remain our most reliable indicator of reproductive success for this subspecies.

Responses to this article can be read online at: https://www.ace-eco.org/issues/responses.php/2021

\section{Acknowledgments:}

All methods in this study were reviewed and accepted by the Animal Care Committee and Banding office (Banding permit \#10700) of the Canadian Wildlife Service. Funding for fieldwork was provided by the Canadian Wildlife Service, Environment and Climate Change Canada with a contribution from the Royal Ontario Museum, the Endangered Species Fund of WWF Canada, and Parks Canada. Many thanks are due to the numerous volunteers who have made the long-term capture-mark-recapture project possible in Mingan, as well as the network of researchers across the globe who have provided resighting data via the BandedBirds website and the Canada Bird Banding Office. Thanks to the Bandedbirds regional project coordinators. Thanks also to Amanda D. Dey, Endangered and Nongame Program, Fish and Wildlife, New Jersey Department of Environmental Protection, Lawrence J. Niles, Conserve Wildlife Foundation, the late Allan Baker, Mark Peck, and Oliver Haddrath from the Royal Ontario Museum, and Patricia M. Gonzalez, Fundacion Inalafquen for providing sexing data. Finally, we thank the staff of the Mingan Archipelago National Park Reserve of Canada for invaluable logistical support.

\section{LITERATURE CITED}

Anderson, A. M., S. Duijns, P. A. Smith, C. Friis, and E. Nol. 2019. Migration distance and body condition influence shorebird migration strategies and stopover decisions during southbound migration. Frontiers in Ecology and Evolution 7: 251. https://doi. org/10.3389/fevo.2019.00251

Andres, B. A., P. A. Smith, R. G. Morrison, C. L. Gratto-Trevor, S. C. Brown, and C. A. Friis. 2012. Population estimates of North American shorebirds. Wader Study Group Bulletin 119 (3):178-194.

Baker, A., P. Gonzalez, R. I. G. Morrison, and B. A. Harrington. 2013. Red Knot (Calidris canutus). The Birds of North America Online, Cornell Lab of Ornithology, Ithaca, New York, USA. https://doi.org/10.2173/bow.redkno.01

Baker, A. J., P. M. Gonzalez, T. Piersma, C. D. T. Minton, J. R. Wilson, H. Sitters, D. Graham, R. Jessop, P. Collins, P. de Goeij, M. K. Peck, R. Lini, L. Bala, G. Pagnoni, A. Vila, E. Bremer, R. Bastida, E. Ieno, D. Blanco, S. de Lima, I. do Nascimento, S. S. Scherer, M. P. Schneider, A. Silva, and A. A. F. Rodriques. 1998. Northbound migration of Red Knots Calidris canutus rufa in Argentina and Brazil: report on results obtained by an international expedition in March-April 1997. Wader Study Group Bulletin 88:65-75.

Baker, A. J., P. M. Gonzalez, T. Piersma, L. J. Niles, I. D. S. do Nascimento, P. W. Atkinson, N. A. Clark, C. D. T. Minton, M. K. Peck, and G. Aarts. 2004. Rapid population decline in red knots: fitness consequences of decreased refuelling rates and late arrival in Delaware Bay. Proceedings of the Royal Society BBiological Sciences 271:875-882. https://doi.org/10.1098/rspb.2003.2663

Bishop, M. A., N. Warnock, and J. Y. Takekawa. 2004. Differential spring migration by male and female Western Sandpipers at interior and coastal stopover sites. Ardea 92:185-196.

Buidin, C., Y. Rochepault, and Y. Aubry. 2010. L'archipel de Mingan: une halte migratoire primordiale pour les oiseaux de rivage. Le Naturaliste Canadien 134(1):73-81.

Buidin, C., Y. Rochepault, and Y. Aubry. 2015. Trapping nonbreeding red knot Calidris canutus with a gunpowder-propelled net-gun. Wader Study 122(1):12-17. https://doi.org/10.18194/ ws.00007

Burnham, K. P., and D. R. Anderson. 2002. Model selection and multimodel inference: a practical information-theoretic approach. Springer-Verlag, New York, New York, USA. 
Committee on the Status of Endangered Wildlife in Canada (COSEWIC). 2007. COSEWIC assessment and status report on the red knot Calidris canutus in Canada. Committee on the Status of Endangered Wildlife in Canada, Ottawa, Ontario, Canada.

Convertino, M., J. B. Elsner, R. Munoz-Carpena, G. A. Kiker, C. J. Martinez, R. A. Fischer, and I. Linkov. 2011. Do tropical cyclones shape shorebird habitat patterns? Biogeoclimatology of Snowy Plovers in Florida. PLoS One 6(1): e15683. https://doi. org/10.1371/journal.pone.0015683

Dormann, C. F., J. Elith, S. Bacher, C. Buchmann, G. Carl, G. Carre, J. R. G. Marquez, B. Gruber, B. Lafourcade, P. J. Leitao, T. Munkemuller, C. McClean, P. E. Osborne, B. Reineking, B. Schroder, A. K. Skidmore, D. Zurell, and S. Lautenbach. 2013. Collinearity: a review of methods to deal with it and a simulation study evaluating their performance. Ecography 36:27-46. https:// doi.org/10.1111/j.1600-0587.2012.07348.x

Environment and Climate Change Canada (ECCC). 2016. Recovery strategy and management plan for the red knot (Calidris canutus) in Canada (proposed). Species at Risk Act Recovery Strategy Series. Environment and Climate Change Canada, Ottawa, Ontario, Canada.

Gaillard, J. M., and N. G. Yoccoz. 2003. Temporal variation in survival of mammals: a case of environmental canalization? Ecology 84:3294-3306. https://doi.org/10.1890/02-0409

Helseth A., Å. Lindström, and M. Stervander. 2005. Southward migration and fuel deposition of red knots Calidris canutus. Ardea 93(2): 213224.

Jolliffe, I. T. 2002. Principal component analysis, Second edition. Springer Verlag, New York, New York, USA.

Juillet, C., R. Choquet, G. Gauthier, J. Lefebvre, and R. Pradel. 2012. Carry-over effects of spring hunt and climate on recruitment to the natal colony in a migratory species. Journal of Applied Ecology 49:1237-1246. https://doi.org/10.1111/

j.1365-2664.2012.02199.x

Lampila, S., M. Orell, E. Belda, and K. Koivula. 2006. Importance of adult survival, local recruitment and immigration in a declining boreal forest passerine, the willow tit Parus montanus. Oecologia 148:405-413. https://doi.org/10.1007/ s00442-006-0386-3

Lank, D. B., R. W. Butler, J. Ireland, and R. C. Ydenberg. 2003. Effects of predation danger on migration strategies of sandpipers. Oikos 103:303-319. https://doi.org/10.1034/j.1600-0706.2003.12314. $\mathrm{x}$

Lathrop, R. G., L. Niles, P. Smith, M. Peck, A. Dey, R. Sacatelli, and J. Bognar. 2018. Mapping and modeling the breeding habitat of the Western Atlantic Red Knot (Calidris canutus rufa) at local and regional scales. Condor 120:650-665. https://doi.org/10.1650/ CONDOR-17-247.1

Lyons, J. E., A. J. Baker, P. M. Gonzalez, Y. Aubry, C. Buidin, and Y. Rochepault. 2018. Migration ecology and stopover population size of Red Knots Calidris canutus rufa at Mingan Archipelago after exiting the breeding grounds. Wader Study Group Bulletin 124(3):197-205 https://doi.org/10.18194/ws.00092

Lyons, J. E., B. Winn, T. Keyes, and K. S. Kalasz. 2017. Postbreeding migration and connectivity of red knots in the western
Atlantic. Journal of Wildlife Management 82:383-396. https:// doi.org/10.1002/jwmg.21389

Mangiafico, S. 2020. rcompanion: functions to support extension education program evaluation ( $\mathrm{R}$ package version 2.3. 26). $\mathrm{R}$ Foundation for Statistical Computing, Vienna, Austria.

McGowan, C. P., J. E. Hines, J. D. Nichols, J. E. Lyons, D. R. Smith, K. S. Kalasz, L. J. Niles, A. D. Dey, N. A. Clark, P. W. Atkinson, C. D. T. Minton, and W. Kendall. 2011. Demographic consequences of migratory stopover: linking red knot survival to horseshoe crab spawning abundance. Ecosphere 2(6):1-22. https:// doi.org/10.1890/ES11-00106.1

Meissner, W. 2005. Variation in timing of the Siberian Knot Calidris $c$. canutus autumn migration in the Puck Bay region (southern Baltic). Acta Ornithologica 40:95-101. https://doi. org/10.3161/068.040.0205

Meltofte, H., Piersma, T., Boyd, H., McCaffery, B., Ganter, B., Golovnyuk, V.V., Graham, K., Gratto-, C. L. Trevor, Morrison, R.I.G., Nol, E., Rösner, H.-U., Schamel, D., Schekkerman, H., Soloviev, M.Y.,, and P. S. Tomkovich, Tracy, D.M., Tulp, I. and Wennerberg, L. 2007. Effects of climate variation on the breeding ecology of Arctic shorebirds. BioScience 59:1-48.

Muraoka, Y., C. H. Schulze, M. Pavlicev, and G. Wichmann. 2009. Spring migration dynamics and sex-specific patterns in stopover strategy in the Wood Sandpiper Tringa glareola. Journal of Ornithology 150:313-319. https://doi.org/10.1007/s10336-008-0351-5

Myers, J. P. 1981. Cross-seasonal interactions in the evolution of sandpiper social systems. Behavioral Ecology and Sociobiology 8:195-202. https://doi.org/10.1007/BF00299830

Niles, L. J., J. Bart, H. P. Sitters, A. D. Dey, K. E. Clark, P. W. Atkinson, A. J. Baker, K. A. Bennett, K. S. Kalasz, N. A. Clark, J. Clark, S. Gillings, A. S. Gates, P. M. Gonzalez, D. E. Hernandez, C. D. T. Minton, R. I. G. Morrison, R. R. Porter, R. K. Ross, and C. R. Veitch. 2009. Effects of horseshoe crab harvest in Delaware Bay on red knots: are harvest restrictions working? Bioscience 59:153-164. https://doi.org/10.1525/bio.2009.59.2.8

Pfister, C. A. 1998. Patterns of variance in stage-structured populations: evolutionary predictions and ecological implications. Proceedings of the National Academy of Sciences of the United States of America 95:213-218. https://doi.org/10.1073/pnas.95.1.213

R Core Team. 2019. R: a language and environment for statistical computing. R Foundation for Statistical Computing, Vienna, Austria.

Schwarzer, A. C., J. A. Collazo, L. J. Niles, J. M. Brush, N. J. Douglass, and H. F. Percival. 2012. Annual survival of red knots (Calidris canutus rufa) wintering in Florida. Auk 129:725-733. https://doi.org/10.1525/auk.2012.11269

U.S. Fish and Wildlife Service (USFWS). 2014. Threatened species status for the rufa red knot. 79 Federal Register 238 (2014 December 11):7370673748.

van Deventer, M., K. Atwood, G. A. Vargo, L. J. Flewelling, J. H. Landsberg, J. P. Naar, and D. Stanek. 2012. Karenia brevis red tides and brevetoxin-contaminated fish: a high risk factor for Florida's scavenging shorebirds? Botanica Marina 55:31-37. https://doi.org/10.1515/bot.2011.122 
Webster, P. J., G. J. Holland, J. A. Curry, and H. R. Chang. 2005. Changes in tropical cyclone number, duration, and intensity in a warming environment. Science 309:1844-1846. https://doi. org/10.1126/science. 1116448

Weiser, E. L., S. C. Brown, R. B. Lanctot, H. R. Gates, K. F. Abraham, R. L. Bentzen, J. Bety, M. L. Boldenow, R. W. Brook, T. F. Donnelly, W. B. English, S. A. Flemming, S. E. Franks, H. G. Gilchrist, M. A. Giroux, A. Johnson, S. Kendall, L. V. Kennedy, L. Koloski, E. Kwon, J. F. Lamarre, D. B. Lank, C. J. Latty, N. Lecomte, J. R. Liebezeit, L. McKinnon, E. Nol, J. Perz, J. Rausch, M. Robards, S. T. Saalfeld, N. R. Senner, P. A. Smith, M. Soloviev, D. Solovyeva, D. H. Ward, P. F. Woodard, and B. K. Sandercock. 2018a. Effects of environmental conditions on reproductive effort and nest success of Arctic-breeding shorebirds. Ibis 160:608-623. https://doi.org/10.1111/ibi.12571

Weiser, E. L., R. B. Lanctot, S. C. Brown, H. R. Gates, R. L. Bentzen, J. Bety, M. L. Boldenow, W. B. English, S. E. Franks, L. Koloski, E. Kwon, J. F. Lamarre, D. B. Lank, J. R. Liebezeit, L. McKinnon, E. Nol, J. Rausch, S. T. Saalfeld, N. R. Senner, D. H. Ward, P. F. Woodard, and B. K. Sandercock. 2018b. Environmental and ecological conditions at Arctic breeding sites have limited effects on true survival rates of adult shorebirds. Auk 135:29-43. https://doi.org/10.1642/AUK-17-107.1

Westemeier, R. L., J. D. Brawn, S. A. Simpson, T. L. Esker, R. W. Jansen, J. W. Walk, E. L. Kershner, J. L. Bouzat, and K. N. Paige. 1998. Tracking the long-term decline and recovery of an isolated population. Science 282:1695-1698. https://doi.org/10.1126/ science.282.5394.1695

Ydenberg, R. C., R. W. Butler, D. B. Lank, B. D. Smith, and J. Ireland. 2004. Western sandpipers have altered migration tactics as peregrine falcon populations have recovered. Proceedings of the Royal Society B-Biological Sciences 271:1263-1269. https:// doi.org/10.1098/rspb.2004.2713

Ydenberg, R. C., A. C. Niehaus, and D. B. Lank. 2005. Interannual differences in the relative timing of southward migration of male and female western sandpipers (Calidris mauri). Naturwissenschaften 92:332-335. https://doi.org/10.1007/ s00114-005-0637-x

Editor-in-Chief: Keith A.Hobson Subject Editor: Dave Shutler
Sponsored by the Society of Canadian Ornithologists and Birds Canada

Parrainée par la Société des ornithologistes du Canada et Oiseaux Canada

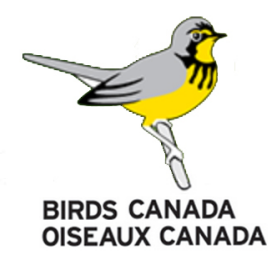

